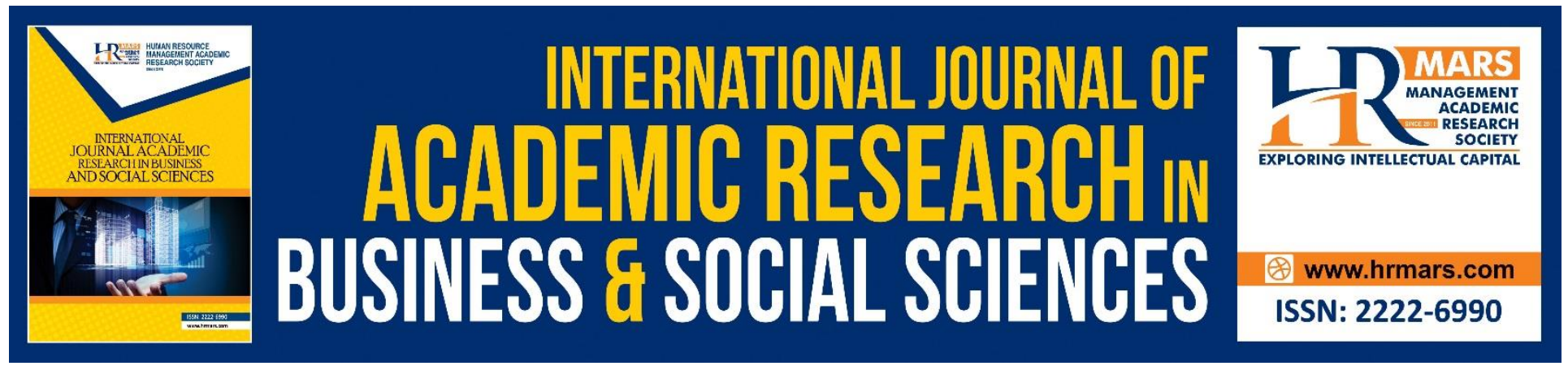

\title{
Factors affecting Firm Performance of SMEs in Malaysia
}

\author{
Najihah Hanisah Marmaya, Noraznira Abd Razak, Melissa Wee, Rizuwan \\ Karim, Abd Rauf Ridzuan
}

To Link this Article: http://dx.doi.org/10.6007/IJARBSS/v8-i10/4779

DOI: $10.6007 /$ IJARBSS/v8-i10/4779

Received: 13 Sept 2018, Revised: 18 Oct 2018, Accepted: 23 Oct 2018

Published Online: 24 October 2018

In-Text Citation: (Marmaya, Razak, Wee, Karim, \& Ridzuan, 2018)

To Cite this Article: Marmaya, N. H., Razak, N. A., Wee, M., Karim, R., \& Ridzuan, A. R. (2018). Factors affecting Firm Performance of SMEs in Malaysia. International Journal of Academic Research in Business and Social Sciences, 8(10), 789-798.

Copyright: (C) 2018 The Author(s)

Published by Human Resource Management Academic Research Society (www.hrmars.com)

This article is published under the Creative Commons Attribution (CC BY 4.0) license. Anyone may reproduce, distribute, translate and create derivative works of this article (for both commercial and non-commercial purposes), subject to full attribution to the original publication and authors. The full terms of this license may be seen at: http://creativecommons.org/licences/by/4.0/legalcode

Vol. 8, No. 10, 2018, Pg. 789 - 798

http://hrmars.com/index.php/pages/detail/IJARBSS

JOURNAL HOMEPAGE

Full Terms \& Conditions of access and use can be found at http://hrmars.com/index.php/pages/detail/publication-ethics 


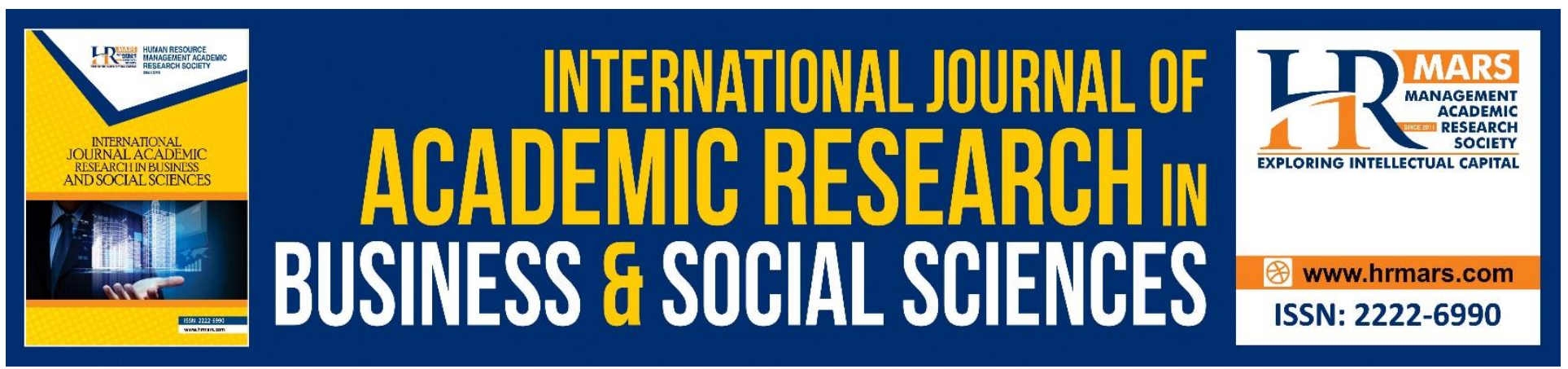

\title{
Factors affecting Firm Performance of SMEs in Malaysia
}

\author{
Najihah Hanisah Marmaya, Noraznira Abd Razak, Melissa Wee, \\ Rizuwan Karim, Abd Rauf Ridzuan \\ Universiti Teknologi MARA, Cawangan Melaka, Malaysia
}

\begin{abstract}
The study purpose is to identify the impact of factors (entrepreneurial orientation, information acquisition, and information utilization) on firm performance of Small Medium Enterprises (SMEs), in Malaysia. A quantitative method was adopted in this study and responses from 150 respondents that were chosen from the list population of SMEs in Malaysia were used. Regression analysis was conducted to test the hypothesis of study and establish the causal effect of entrepreneurial orientation, information acquisition, and information utilization towards firm performance of SMEs. The findings show that only two factors (information acquisition and information utilization) influence firm performance while entrepreneurial orientation was not found to relate with firm performance. Based on the results, the researcher found that information utilization was the most influence factors on firm performance of SMEs. The researcher suggests that SMEs should strengthening the effective marketing strategy or formulation of their business. Besides that, to improve acquire information of SMEs, they should be creative and innovative. Future study should increase sample size, choose multiple background industry, use qualitative methods or use other factors to relate with the performance of SMEs.
\end{abstract}

Keywords: Entrepreneurial orientation (EO), Information Acquisition (IA), Information Utilization (IU), Firm performance, Small Medium and Enterprises (SMEs)

\section{Introduction}

Historically, entrepreneurship is one amongst the oldest activities. To find or establish new business prospects and to take advantage of these prospects in new ventures for economic gain has continually been vital in human life. With today's complexness in conducting business transactions, entrepreneurial orientation (EO) may be considered a dynamic issue to confirm the success of a business. At an equivalent time, companies' are forced to be concerned in seeking out new opportunities. The link between entrepreneurial orientation (EO) and firm performance has become the most subject of interest in past literatures. Over the previous few years, ample proof has been provided in support of the very fact that a market orientation and an entrepreneurial orientation are 
related to positive business performance (Kirca, Jayachandran and Bearden 2005). As reported by the Malaysian Department of Statistics in 2016, 907,065 total SMEs establishments in Malaysia, comprise of 2.3\% medium SMEs, 21.2\% Small SMEs and 76.5\% Microenterprises SMEs by size. SMEs comprise of 3 key economic sectors particularly producing, services and agriculture. Microenterprises represent the most important range with over three quarters out of the entire SMEs formations. They are primarily diagrammatic within the services and agriculture sectors with the proportions for 80.4 and 93.3 percent severally. Small corporations conjure to 18.4 percent and medium corporations 2.2 percent. The manufacturing sector additionally displayed identical patterns however the share of small corporations was lower (55.3 percent), whereas small corporations accounted to 39.5 percent. SMEs in Malaysia, is classified into 3 components; (1) general business, (2) producing and (3) agricultures. The overall sector includes construction, wholesaling and selling, transport and storage, business services and activities, and providing services like hotel and restaurant. The most activities within the producing sector incorporate process and production of raw materials. In the meantime the agriculture sector includes oil palm, rubber, paddy, coconuts, fruits, and vegetables. From the 3 elements; the producing sector emerged because the most significant component for SMEs in Malaysia. Despite the importance of SMEs in a country's economic development, the fact that SMEs owners are not aware of the business challenges, especially in terms of financial and management skills is a reality (Beh, 2013). The failure rate is alarming high for the first five years among many small firms (Ahmad and Seet, 2009). In Malaysia, the failure rate is at 60 percent and this need absolute attention from the authority (Nordin, Hamid \& Woon, 2011; Chong, 2012; Husin \& Ibrahim, 2013). Therefore, this study contributes to the literature by addressing the existing gap and attempts to diagnose the factors contribute to SMEs firm performance in Malaysia. The empirical results will provide a reasonable reference and motivation for improving firm performance and reduce the failure rate among SMEs in Malaysia.

\section{Firm Performance}

The thought of firm performance has to be distinguished from the broader construct of structure effectiveness. According to santos \& Brito, (2012) the definition of firm performance and its activity continues to challenge students because of its complexness. Superior money performance could be a way to meet investors' need and may be depicted by profit, growth and market price (Cho \& Pucik, 2005). Growth demonstrates a firm's past ability to extend its size. Increasing size, even at an equivalent profit level, can increase its absolute profit and money generation. Larger size can also bring economies of scale and market power, prompting to upgrade future profit. Market price represents the external assessment and expectation of firms' future performance. It ought to have a correlation with historical profit and growth levels, however conjointly incorporate future expectations of market changes and competitive moves.

\section{Conceptual and Hypotheses Development}

The conceptual development consists of the impact of entrepreneurial orientation, information acquisition and information utilization on firm performance. Based on these, the following discussion explains and hypothesizes the simultaneous relationship between the relationships. 
INTERNATIONAL JOURNAL OF ACADEMIC RESEARCH IN BUSINESS AND SOCIAL SCIENCES

Vol. 8, No. 10, Oct. 2018, E-ISSN: 2222-6990 @ 2018 HRMARS

\section{The impact of entrepreneurial orientation on firm performance}

There has been growing research interest in the field of entrepreneurial orientation (EO), particularly in small businesses. As stated by Keh, Nguyen, \& Ng (2007), the literature indicates that entrepreneurial orientation (EO), has an optimistic impact on firm performance. Although, the prior research has establish that firms with high levels of EO tend to persistently scan and monitor their operating environment in order to find new ventures and reinforce their competitive positions. Specifically, the EO is proven to have a direct impact on firm performance. Thus, entrepreneurial orientation (EO) has received substantial conceptual and empirical attention, expressive one of the few areas in entrepreneurship study where a growing body of knowledge is developing. The time is therefore ripe to document, review, and evaluate the cumulative knowledge on the relationship between $\mathrm{EO}$ and business performance.

Hypothesis 1: Entrepreneurial orientation relates with firm performance

\section{The impact of Information Acquisition on firm performance}

Information acquisition is the process involved in bringing information about the external environment into the boundary of the organization (Moorman's, 1995). Companies prefer to grow by getting others to extend market share, to achieve access to promising new technologies, to attain synergies in their operations, to faucet well-developed distribution channels, to get management of undervalued assets, and a myriad of alternative reasons. However acquisition may be risky as a result of several things will fail with even a well-laid attempt to grow by acquiring: Cultures could clash, key workers could leave, synergies could fail to emerge, assets could also be less valuable than perceived, and prices could skyrocket instead of fall. Still, maybe due to the attractiveness of instant growth, acquisition is an increasingly common way to expand. Generally, information acquisition is one in all the vital determinants of investment that can influence investors' monetary alternative. The knowledge search literature provides decent proof that investors use varied information search methods to assist them build commercialism choices which are normally supported frequency criteria: the time spent on data search; the quantity of contacts by phone or visit; and also the number of sources accustomed gather data (Klein \& Ford, 2003). Within the era of globalisation and continuously dynamic business environments, the necessity for continued empowering information acquisition is changing into ever increasing. Information acquisition and learning are well emphasised as vital factors to successful entrepreneurship over the last decades. Failure to assemble new information and learn will cause a firm to be unable to keep up with technological progress since it's going to be incapable of manufacturing technology standards.

The term that integrates the ideas of entrepreneurship and also the information attained through the acquisition of data is 'knowledge based entrepreneurship'. This term came in the recent literature and it's extremely connected with the processes that interconnect the creation of novel information to the creation valuable for each entrepreneurial organization. Using a broader approach, the market data acquisition method objectives is to outline the markets that the corporate merchandise are often oversubscribed productively, the markets with the simplest entrepreneurial potential, the tendency product changes that might be applied so as the merchandise to be oversubscribed within the market, the obtainable positioning channels, the market competition and also the peculiar 
market scenario, the valuation strategy that ought to be followed in every market and lots of additional. To summarize all of the past literature those are compiled, (Garri \& Konstantopoulos, 2013) explicit that entrepreneurship, market data and market data acquisition area unit interconnected. Garri \& Konstantopoulos (2013), highlight that entrepreneurs ought to explore opportunities to boost the manner during which market data is obtained such as effort multiple forms of market data, exploitation completely different sources in getting market information to dependably support their entrepreneurial activities. Consequently, management may plan the method during which market intelligence is subtle throughout the organization, so as the utmost level of market data exploitation and market data generation to be achieved.

Hypothesis 2: Information Acquisition relates with firm performance

\section{The impact of Information Utilization on firm performance}

The simple definition of information utilization in the export setting is one of providing a measurement of the extent to which information influences decision-making within a company (Souchon et al.,1997). As opposed to information need or acquisition, which is influenced by both external forces and internal requirements, information utilization is completely internal function of the company. Organizational factors, such as corporate and national culture, market orientation and organizational structure play a critical role in how a company processes the information obtained in the information acquisition stage of the information life cycle. Organizational forces at play within the company influences and are a Akinboye (2003) observed that information utilization assists managers in organizations to build their own boundaries of thinking and to have more unique perceptions and cognitions in order to enhance their level of creativeness. Besides that, acquire and utilize appropriate and relevant information sources may improve their creative thinking for better job performance Information utilization (IU) is particularly important to firms' final decisions, because information is deemed to be worthless unless it is put to good use. Menon and Varadarajan (1992) suggest that information utilization be conceptualized in terms of type and extent of usage in the decision-making process. They classify information utilization into action-oriented use, knowledgeenhancing use and affective use. Action-oriented use refers to information utilization that results in changes in the user's activities, practices or policies; knowledge enhancing use would change the user's knowledge; while affective use would change the user's psychological status, such as her satisfaction or dissatisfaction, confidence or lack thereof, and trust or mistrust. According to Soh (2003) the information exquisite customer's information, competitor information and product information. The utilization of information regarding customers and competitors to improve marketing decision-making is considered to be the basic building block of market orientation (MO). Thus, the better utilization of marketing information would lead to a higher performance.

Hypothesis 3: Information utilization relates firm performance 
INTERNATIONAL JOURNAL OF ACADEMIC RESEARCH IN BUSINESS AND SOCIAL SCIENCES

Vol. 8, No. 10, Oct. 2018, E-ISSN: 2222-6990 @ 2018 HRMARS

\section{Methodology}

\section{Measurement}

The study used cross-sectional survey data collected from SMEs. The measurements are developed based on extensive reviews of the literature. The survey is divided into two sections: the first section is designed to collect information on respondents' demographic profile, while the second section contains measurements on theoretical constructs for the present study. Second section consists of questions related to entrepreneurial orientation (D. Miller, P.H. Friesen, 1982), information acquisition (L. Johnson, R. Kuehn, 1987), information utilization (Diamantopoulos and Souchon, 1999) and firm performance Gupta and Govindarajan (1984). The survey is measured using the five-point Likert scale (i.e. 1=strongly disagree and 5=strongly agree). A pre-test study is carried out using 50 SMEs. The respondents are a relatively homogeneous population suitable for theory testing and development. They also represent a growing target market for the research context and are therefore considered appropriate for the present study. From this initial pretest, several questions are rephrased to improve the instrument's readability.

\section{Sample}

The present study distributes a total of 170 questionnaires to SMEs. The collected responses are later screened and examined for incomplete responses and credibility. This initial procedure has resulted in the removal of 20 incomplete or unreliable responses (i.e. out of 170), thus leaving a total of 150 usable responses throughout the three regional locations. The data obtained are analysed using SPSS 20.

\section{Result}

Most of the respondents are male (67.3\%) followed by female (32.7\%). Bachelor Degree as the highest educational background (35\%) followed by Diploma (15\%), and SPM level (50\%). Most of the respondents are between $31-40$ years old which contribute $32.7 \%$ of the total respondents whereas the second highest would be between $41-50$ years old with $31.3 \%, 51$ and above years old $22 \%$ and number of respondents at age 19-30 years old contribute the remaining $14 \%$. Majority of the respondents have experience in 6 to 10 years in doing the business (40.7\%) followed by experience more than 10 years (36.7\%), and followed by 5 years business experience $(22.7 \%)$. The reliability coefficient of factor structures is measured using the Cronbach's alpha. The coefficient alpha values for the five constructs range from 0.54 to 0.95 , demonstrating good internal consistency and strong reliability of each dimension (Hair et al., 2010). Multiple regression analysis was used to test the hypotheses.

Table 1: Hypothesis Testing

\begin{tabular}{|l|c|c|c|c|}
\hline Hypotheses & Beta & T Statistics & P Values & $\begin{array}{c}\text { Hypothesis } \\
\text { accepted/rejected }\end{array}$ \\
\hline $\begin{array}{l}\text { H1:Entrepreneurial } \\
\text { Orientation }\end{array}$ & 0.074 & 1.234 & 0.219 & Rejected \\
\hline H2: Information acquisition & 0.195 & 2.231 & 0.027 & Accepted \\
\hline H3:Information Utilization & 0.587 & 6.444 & 0.00 & Accepted \\
\hline
\end{tabular}

Dependent Variable: Firm Performance 
Table 1, shows the results of the hypotheses relationships. The analysis suggests a strong support on two of our posited hypotheses (i.e. $\mathrm{H} 2$ and $\mathrm{H} 3$ ). The result for $\mathrm{H} 1$ is rejected. The analysis of $\mathrm{R}^{2}$ for firm performance is 0.51 . The result discovers that 52.1 per cent of the variation for firm performance could be explained by the dimension of entrepreneurial orientation, information acquisition and information utilization. Following Hair et al. (2010), $\mathrm{R}^{2}$ values meet the requirement of 0.2 or 20 per cent in the consumers' research, suggesting that the current model is acceptable.

\section{Discussion}

This study discovers a non-significant relationship between entrepreneurial orientation and firm performance. The positive linear relationship between entrepreneurial orientation and firm performance has been wide mentioned and examined by several western scholars (Keh et al., 2007) but still there are some arguments about the relationship. Wiklund and Shepherd, (2003) argued that the relationship may be more complex than a simple main-effects-only relationship. More of that, Lyon et al., (2000) mentioned that the strength of the direct relationship between entrepreneurship and performance is generally less vigorous than the normative belief would indicate. Thus, more researchers are needed to test moderated effect and act reciprocally on the EO performance contingent rather than direct relationship, and provide more accurate explanations of performance outcomes. Second hypothesis is supported by previous study which is, there is a relationship between information acquisitions with firm performance. Moorman (1995) in his previous study mentioned information acquisition showed significant and positive impact on information utilization, which in turn enhanced firm performance. Third hypothesis also shows that there is a relationship between information utilization with firm performance of SMEs. The previous study by Im and Workman, (2004) mentioned that information utilization to be important activities, particularly salient for firms that have high levels of entrepreneurial orientation.

\section{Contribution}

This finding has important effects for entrepreneurs to diagnose the factors contribute to SMEs firm performance in Malaysia. Entrepreneurs should actively engage in information acquisition and fully utilize the information as an aid to excellent marketing strategy formulation. Precisely, proactively use of such information allows entrepreneurs to target oncoming trends and enact strategies, supporting the view that the competitive advantage associated with information depends increasingly on whether a firm is able to make the best use of acquired information (Moorman, 1995). Keh, Nguyen, \& Ng, (2007) infer that business owners should have creative, proactive and risk-taking ways to seek innovative information and utilize the acquired information. Consistent with Im and Workman (2004) study the firms that closely monitor customers' needs tend to enhance creativity by producing novel and meaningful offerings and marketing programs that, in turn, reinforce organizational innovations through the firm's entire business system. The growing trend of SME establishment warrants more research to be done, especially in the Malaysian case study, in order to improve and consequently leading to the SME success. So, the small business owners know what to expect and take action before it is too late. On the other hand, limitations of this paper include lack of number of respondents. It is recommended that future researcher that intends to study this topic 
INTERNATIONAL JOURNAL OF ACADEMIC RESEARCH IN BUSINESS AND SOCIAL SCIENCES

Vol. 8, No. 10, Oct. 2018, E-ISSN: 2222-6990 ㄷ 2018 HRMARS

should increase the number of sample size and test additional moderating or mediating variable such as entrepreneurial culture or entrepreneurial capability in the study.

\section{Corresponding Author}

Dr Najihah Hanisah bte Marmaya

UiTM Kampus Bandaraya Melaka

110 Off Jalan Hang Tuah

75300 Melaka, MALAYSIA Email: najihah_02@yahoo.com

\section{References}

Ahmad, N.H. \& Seet, P. (2009) 'Dissecting Behaviours Associated with Business Failure: A Qualitative Study of SME Owners in Malaysia and Australia', Journal of Asian Social Science, vol. 5 (9), pp. 98104.

Akinboye, J. O. (2003). Creativity and Innovation in Education. In: O. AyodeleBamisaiye, I. A. Nwazuoke, A. Okediran, Education Thus Millennium: Innovations in Theory and Practice, Ibadan: Macmillan Nigeria Publishers Limited.

Beh, B. (2013) 'Why small businesses bite the dust,' viewed 10 December 2014, .

Cho, H., \& Pucik, V. (2005). Relationship between innovativeness, quality, growth, profitability, and market value. Strategic Management Journal, 26(6), 555-575. doi:10.1002/smj.461

Chong, W.Y. (2012) 'Critical Success Factors for Small and Medium Enterprises: Perceptions of Entrepreneurs in Urban Malaysia', Journal of Business and Policy Research. vol. 7 (4), pp. 204-215

Miller D. and Friesen, P. H. (1982). 'Innovation in conservative and entrepreneurial firms: Two models of strategic momentum', Strategic Management Journal, 3, pp. 1-25.

Department of Statistics, Malaysia in 2016 retrieved from http://www.dosm.gov.my

Garri, M., \& Konstantopoulos, N. (2013). Market Information Acquisition: A Prerequisite for Successful Strategic Entrepreneurship. Procedia - Social and Behavioral Sciences, 73, 643-651. doi:10.1016/j.sbspro.2013.02.101

Gupta, A.K and V. Govindarajan (1984), Business unit strategy, managerial characteristics and business unit effectiveness at strategy implementation, Academy of Management Journal, 27 (1):2441

Hair, J.F., Black, W.C., Babin, B.J. and Anderson, R.E. (2010). Multivariate Data Analysis. 7th ed.,Prentice Hall, Englewood Cliffs. 
INTERNATIONAL JOURNAL OF ACADEMIC RESEARCH IN BUSINESS AND SOCIAL SCIENCES

Vol. 8, No. 10, Oct. 2018, E-ISSN: 2222-6990 @ 2018 HRMARS

Husin, MA \& Ibrahim, MD 2014, 'The Role of Accounting Services and Impact on Small Medium Enterprises (SMEs) Performance in Manufacturing Sector from East Coast Region of Malaysia: A Conceptual Paper', Procedia-Social and Behavioral Sciences, 115, pp. 54-67.

Im, S., \& Workman, J.P. (2004). "Market Orientation, Creativity, and New Product Performance in High-Technology Firms", Journal of Marketing, 68 (2): 114-132.

Keh, H. T., Nguyen, T. T., \& Ng, H. P. (2007). The effects of entrepreneurial orientation and marketing information on the performance of SMEs. Journal of Business Venturing, 22(4), 592-611. doi:10.1016/j.jbusvent.2006.05.003

Johnson, J. L. \& Kuehn, R. (1987) The small business owner/manager's search for external information, Journal of small business management 25. pp. 53-60.

Kirca, A. H., Jayachandran, S., \& Bearden, W. O. (2005). Market Orientation: A Meta-Analytic Review and Assessment of Its Antecedents and Impact on Performance. Journal of Marketing, 69(2), 24-41. doi:10.1509/jmkg.69.2.24.60761

Klein, L. R., \& Ford, G. T. (2003). Consumer search for information in the digital age: An empirical study of prepurchase search for automobiles. Journal of Interactive Marketing, 17(3), 29-49. doi:10.1002/dir.10058L.

Lyon, D. W. (2000). Enhancing Entrepreneurial Orientation Research: Operationalizing and Measuring a Key Strategic Decision Making Process. Journal of Management, 26(5), 1055-1085. doi:10.1177/014920630002600503

Menon, A., \& Varadarajan, P. R. (1992). A Model of Marketing Knowledge Use within Firms. Journal of Marketing, 56(4), 53. doi:10.2307/1251986

Moorman, C. (1995). Organizational Market Information Processes: Cultural Antecedents and New Product Outcomes. Journal of Marketing Research, 32(3), 318.doi:10.2307/3151984

Santos, J. B., \& Brito, L. A. (2012). Toward a subjective measurement model for firm performance. BAR. Brazilian Administration Review, 9(spe), 95-117. doi:10.1590/s1807-76922012000500007

Soh, P. (2003). The role of networking alliances in information acquisition and its implications for new product performance. Journal of Business Venturing, 18(6), 727-744. oi:10.1016/s08839026(03)00026-0

Souchon, A. L., \& Diamantopoulos, A. (1997). Use and non-use of export information: Some preliminary insights into antecedents and impact on export performance. Journal of Marketing Management, 13(1-3), 135-151. doi:10.1080/0267257x.1997.9964463 
INTERNATIONAL JOURNAL OF ACADEMIC RESEARCH IN BUSINESS AND SOCIAL SCIENCES

Vol. 8, No. 10, Oct. 2018, E-ISSN: 2222-6990 @ 2018 HRMARS

Wiklund, J., \& Shepherd, D. (2003). Aspiring for, and Achieving Growth: The Moderating Role of Resources and Opportunities. Journal of Management Studies, 40(8), 1919-1941. doi:10.1046/j.14676486.2003.00406.x 